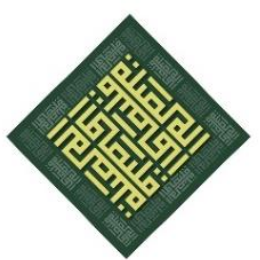

El-Mashlahah

Volume 11 No. 2, December 2021

ISSN: E-ISSN: 2622-8645; P-ISSN: 2089-1970

DOI: $10.23971 /$ elma.v11i2.3108

\title{
GOVERNMENT POLICIES IN ECONOMIC EMPOWERMENT OF MUSLIM COMMUNITIES IN THE DIGITAL ECONOMY ERA
}

\author{
Fajar Sukma, Zulheldi \\ Postgraduate, UIN Imam Bonjol Padang, Indonesia \\ fajarsukma81@gmail.com
}

Received: 15-07-2021; Accepted: 15-11-2021; Published: 23-12-2021;

\begin{abstract}
This article highlighted the role and policies of the government and its staff in carrying out the tasks or functions of community empowerment, including identifying the supporting and hindering factors in the community empowerment process. Community empowerment also has several principles in its implementation, namely awareness of the community, providing education and training, organizing, developing strengths, and developing dynamics (decisions in the hands of the community itself). Community empowerment is focused on various aspects related to people's lives as a nation's society, namely empowerment in the fields of education, economy, socio-culture, psychology, and politics in the era of the digital economy. Through literature studies and qualitative approaches aimed to examine and interpret the events related to policies and the role of government, then compare to Islamic governments in the past. In the era of Amirul Mukminin bin Al-Khattab as the second caliph, he ran the government firmly but was very sensitive to his people. The policies, that he issued, were for the benefit of the people, not only Muslims but also all citizens who live in the authority of Umar's caliphate. These policies in community empowerment during Umar's time should be interpreted in the current context. The era is known as the digital age, of course, it needs to modify the policies of the previous era so that they can be relevant and able to be implemented in real terms.
\end{abstract}

Keywords: Government Policy; Community Empowerment; and Digital Economy Era;

\section{ABSTRAK}

Artikel ini menyoroti peran dan kebijakan pemerintah dan jajarannya dalam menjalankan tugas atau fungsi pemberdayaan masyarakat, termasuk mengidentifikasi faktor pendukung dan penghambat proses pemberdayaan masyarakat. Pemberdayaan masyarakat juga memiliki beberapa prinsip dalam pelaksanaannya, yaitu penyadaran terhadap masyarakat, memberikan pendidikan dan pelatihan, pengorganisasian, pengembangan kekuatan, dan pengembangan dinamika (keputusan di tangan masyarakat itu sendiri). Pemberdayaan masyarakat difokuskan pada berbagai aspek yang berkaitan dengan kehidupan masyarakat sebagai masyarakat bangsa, yaitu pemberdayaan di bidang pendidikan, ekonomi, sosial budaya, psikologi, dan politik di era ekonomi digital. Dengan melakukan studi pustaka dan pendekatan kualitatif untuk menelaah dan menginterpretasikaan kejadian-kejadian yang terkait dengan kebijakan serta peran pemerintah dan membandingkannnya dengan pemerintahan Islam di masa lalu. Di era Amirul Mukminin bin Al-Khattab sebagai khalifah ke dua, ia menjalankan

https://e-journal.iain-palangkaraya.ac.id/index.php/maslahah/index 
pemerintahan dengan tegas namun sangat peka terhadap rakyatnya. Kebijakankebijakan yang dikeluarkannya adalah untuk kemaslahatan umat, tidak hanya umat muslim tetapi juga seluruh warga yang berada dalam naungan kekhalifahan Umar. Kebijakan-kebijakan dalam pemberdayaan masyarakat di masa Umar tersebut patut diintepretasikan pada konteks sekarang. Zaman yang dikenal dengan zaman digital tentu perlu modifikasi kebijakan era dulu, sehingga dapat relevan dan mampu diterapkan secara nyata.

Kata Kunci: Kebijakan Pemerintah; Pemberdayaan Masyarakat; dan Era Ekonomi Digital;

\section{Introduction}

An article in the Iqtishaduna journal, written by Zakaria Batubara ${ }^{1}$ discusses the state distributing wealth to individual people equally, regardless of their position and social status. The result is, even all people get the same wealth, but there is no proper appreciation for everyone's efforts. Because no matter how much effort and productivity they produce, they still get the same distribution of wealth as other peoplewho may gives a small or no work at all. This is the reason, why the socialist economic system rejects the market mechanism (price) in the distribution of wealth. In other journal, Dinar Muhammad Idril Gufron ${ }^{2}$ discusses on increasing the production of the Islamic economic system as economic empowerment of the people. He discusses on the topic of increasing the production system in Islam means increasing income that is measured in terms of money and maximizing the fulfillment of needs with minimal effort. But, it should consider to Islamic demands on consumption side. Moreover, increasing production is also done by optimizing the sources or drive of production of the people to improve the community's economy, such as zakat, taxes, bait al-māl wa al-tamwil, sharia banks, and so on. The novelty of this paper was a review of the role and policies of the Islamic Government in the past and the efforts made in the present.

One of the Local Government's tasks is to empower the community to raise the standard of life for their people. Thus, government apparatus in the region are always required to take a large role in empowering the communities in the region. The community empowerment idea relates toGriffin's idea that the issue and urgency of

${ }^{1}$ Zakaria Batubara, "Islam Dan Pemberdayaan Ekonomi Umat,” Iqtishaduna 2, no. 2 (2013): 52448, https://ejournal.stiesyariahbengkalis.ac.id/index.php/iqtishaduna/article/view/34.

2 Moh. Idril Gufron, "Peningkatan Produksi Dalam Sistem Ekonomi Islam Sebagai Upaya Pemberdayaan Umat," Dinar: Jurnal Ekonomi Dan Keuangan Islam 2, no. 1 (2015), https://journal.trunojoyo.ac.id/dinar/article/view/2690. 
decentralization policy are closely related to the issue of empowerment, in the sense of giving flexibility and authority to the Government at the regional level to perform their tasks, as well as the authority and responsibility of local government organizations to develop programs, choose an alternative, and take decisions in taking care of their regional interests. ${ }^{3}$

Community empowerment is an economic development concept that incorporates social values. This concept reflects a new development paradigm that is peoplecenetred, participatory, empowering, and long-term. The concept of empowerment is broader than just an effort to meet basic needs or just a mechanism to prevent further impoverishment. ${ }^{4}$ Then, what is the concern today? How is the role of the Government in doing community empowerment, and how is the Islamic view in the empowerment of the community itself?

\section{Method}

The methods of discussion in the preparation steps were descriptive, documentative, and comparative. The preparation was carried out by collecting data, explaining and describing information related to the planning and design of community economic empowerment that conducted by the Government inspired by the Islamic economy. The type of the research was normative legal research ${ }^{5}$ using a qualitative approach through literature studies to obtain transparent information from the datasources such as journals, thesis, and other scientific papers to obtain relevant source. ${ }^{6}$ The steps during data collection were a Descriptive Methods that focused on the description and exposure related to government policies in economic empowerment of muslim communities in the digital economy era.

3 Suharyono A R, Role Government, Empowerment Society, and Enforcement Law Depp Countermeasures Logging Wild (Jakarta: Yayasan Pustaka Torch Indonesia, 2018).

${ }^{4}$ Meirison and Zerly Nazar, "Intellectual Property Rights and Monopoly in the Perspective of Islamic Jurisprudence," Al-Ahkam 31, no. 1 (2021): 49-68, https://doi.org/10.21580/ahkam.2021.31.1.6656.

5 Sabarudin Ahmad, "Hukum Aborsi Akibat Perkosaan (Analisis Hukum Islam Terhadap Peraturan Pemerintah Nomor 61 Tahun 2014 Tentang Kesehatan Reproduksi," El-Mashlahah 8, no. 2 (2018): 162-83, https://doi.org/https://doi.org/10.23971/el-mas.v8i2.1321.

${ }^{6}$ Desi Refnita, "The Mustahik Zakat in Various Dimensions of Fiqh in Era Society 5.0," ElMashlahah 11, no. 1 (2021): 13-28, https://doi.org/10.23971/elma.v11i1.2285. 


\section{Findings and Discussion}

The four main contexts of Islamic economics for SDGs in the industrial revolution era 4.0 were; discussed using the theories from maqāsid syari' 'ah, alignment of SDGs with maqāsid syari' ah and Islamic economics, how the industrial revolution 4.0 has an impact on the Islamic economy, as well as education and research on the Islamic economy in the industrial revolution era 4.0. Payne also stated that, the power-ping process is intended to help clients gain power over decisions and actions through the way of reducing the effects of personal and social barriers to training existing power by increased the ability and confidence to use power. Also, through the transfer of power from their environment, which the clients supposed to be individuals, families, groups, and communities, with empowerment as a process, it is expected can control their lives and determine the future they want. ${ }^{7}$

The purpose of community empowerment according to Sumodiningrat are:

1) Increase people's income to reduce poverty.

2) Conduct productive socio-economic activities to develop the capacity of the community.

3) They are improving the institutional capacity in the community to provide optimal results in the service.

Three important strategies in social development, according to Midgley, are:

1) Social development through individuals. is an individual action in the community to self-help in a community service efforts to empower the community.

2) Social development through the community. is community groups action jointly together to develop their local communities.

3) Social development through Government. is social development carried out by institutions of government organizations. ${ }^{8}$

Thus, not only individuals and communities do empowerment activiites, but also the Government. The Government's role in the empowerment process is urgent because

${ }^{7}$ Sumodiningrat, Empowerment Society and Dragnet Safety Social (Jakarta: Gramedia Pustaka Utama, 1999).

${ }^{8}$ James Midgley, Social Development: The Development Perspective in Social Welfare (London: Thousand Oaks Calif, 1995). 
the Government has significant power to assist the community in becoming more empowered and, as a result, more prosperous. ${ }^{9}$

Community empowerment is about improving community power/independence or prepare the community in the form of resources, knowledge, opportunities, and skills. Those activity aims to improves the community's capacity to determine their future, and to participate and influence the life of the community itself, including the empowerment of education, economy, socio-cultural, psychology, and politics. The successfull of the function of local government is, when the local community has been empowered from the sides of education, economy, socio-culture, psychology, and politics. ${ }^{10}$

According to Watson as quoted by Adi, the obstacles that play as barrier to a changeand undoubtedly be barrier in empowerment efforts through community intervention, are:

1) Barriers are from individual personalities, such as stability (homeostasis), habit, perception and memory, dependency, high-ego, self-distrust, and insecurity and regression.

2) Barriers are from the social system, such as agreement on certain norms (conformity to norms), unity and cohesion of the system and culture, vested interests, sacred things (the heavenly), and rejection of outsiders. ${ }^{11}$

The Indonesian Government has a mandatory to protect all of the region and Indonesian people, advance the welfare, educate the nation's life, and implement the world order. The statement means that the Government has a central role in planners, mobilizers, controllers, and supervisors in implementing national development. ${ }^{12}$ The failure and success of community development and empowerment are determined by the ability of all parties involved in the community development process to understand the reality of society. The importance of development and empowerment is a national

\footnotetext{
9 Eman Assi, "Islamic Waqf and Management of Cultural Heritage in Palestine," International Journal of Heritage Studies 14, no. 4 (2008): 380-85, https://doi.org/10.1080/13527250802156180.

10 Onny S. Prijono and A.M.W. Pranarka, Empowerment: Concept, Policyand Implementation (Jakarta: Centre for Strategic and International Studies, 1996).

11 Adi Isbandi Rukminto, Empowerment, Development Society, and Intervention Community (Jakarta: F-UI, n.d.).

12 Muhammad Azran Labaran, Lukman Hakim, and Rudi Hardi, "The Role of The Local Government in the Empowerment of Cocoa Farmers Community in Taan Village, Tapalang District, Mamuju Regency," Otoritas: Jurnal Ilmu Pemerintahan 4, no. 1 (2014), https://doi.org/0.26618/ojip.v4i1.80.
} 
development mechanism that makes the community act as the main actors of development activities, starting from planning, implementation, evaluation, to followup. Therefore, it needs a legal protection for implementing a national development system based on community empowerment and the Indonesian Islamic Spirit to bridge the micro context into a macro context and, vice versa. Giving a mandate on the Government's impartiality as a facilitator in national development to provides an active role to the participative community.

According to Labolo, government functions are divided into three:

1) Service functions are grouped into civil service and public service. Although performed on individuals or private, civil service is a service, while public services are a need because it has an exceptional value. This function lead to a basic definition of Government that, as a science knowledge, the Government learns how to meet and protect the needs and demands of each individual for public services and civil service.

2) The function of regulation, is the services provided by the Government to the function of regulation. For example issued and enforce regulations to regulate special activities, such as land use, building standards, entertainment, public service, etc.

3) Development functions. Regional governments may be directly involved in forms of economic activity, such as the optimization of factories, plantations, forestry, and trade businesses. The activities are undoubtedly prevalent in social countries. It can be attempted to ground foreign business interests in other countries to encourage and set an example to the private sector. Through this development function, the Government is expected to support private companies to improve facilities and infrastructure and the public in the sector of agriculture, livestock, fisheries, or industry. ${ }^{13}$

According to Pranarta and Prijono, empowerment is performed until the target community can be independent without any guidance. This opinion imply the empowerment is through a period of the learning process until achieving independent status. Nevertheless, the concept must keep its independence continously, such as the

\footnotetext{
${ }^{13}$ Labaran, Hakim, and Hardi.
} 
spirit, condition, and ability that not to re-back to prior condiiton. This concept of community empowerment arises because of the failure and the goal of the action itself. ${ }^{14}$

Empowering the community can be viewed from three angles. First, creating an atmosphere or climate that allows to develop the community's potential. Second, developing the community's potential. Third, enabling the community's potential. The introduction, here, is that every human being, every society, they has potential to be developed. There is no society without power; if there is, it will become extinct. Empowerment is an effort to build that power by encouraging, motivating, and raising awareness of its potential and seeking to develop it. Second, empowering the potential or power of the community. ${ }^{15}$ To realize it, it takes more positive measures, apart from just creating a climate and atmosphere. This strengthening actions include concrete steps, concerns the provision of various inputs, and opens access to various opportunities to empower the community. It is also important to emphasize the impact aspect. The impact is considered as the most vital thing and is felt directly by the community and the environment. They also hope, this action would continuous to be held. The Islamic economy can be applied in Indonesia and had a lasting impact on development during the industrial revolution era 4.0. The community can reach the lowest level and the availability of funding, training, and marketing institutions in rural areas, where concentrated power is severely low. ${ }^{16}$

Therefore, there needs a particular program for the underprivileged because the prevailing public programs can not always touch this layer of society. Friedman stated, "The empowerment approach, which is fundamental to an alternative development, emphasizes autonomy in the decision marking of territorially organized communities, local self-reliance (but not autarchy), direct (participatory) democracy, and experiential social learning." Third, empowering also means protecting. In the empowerment process, it must be prevented that the weak become weaker because of the lack of power to face with the stronger. Therefore, protection and empowerment of the weak are very fundamental in the concept of community empowerment. Protecting does not mean

\footnotetext{
${ }^{14}$ Labaran, Hakim, and Hardi.

15 Meirison, Fadhilah Insani, and Zahara Andini, "Epistemology of Basic Concepts of Spiritual and Physical Thaharah: Analysis of The Benefits of Ablution Spiritually and Physically," Al-Insyiroh 7, no. 1 (2021): 26-43, https://doi.org/10.35309/alinsyiroh.v7i1.4080.

16 Abdurrahman, Encyclopedia Economics, Finance and Trade: English-Indonesia (Jakarta: Pradnya Paramita, 1991). 
isolating or masking from interactions because it will precisely be excommunicated. Protecting should be viewed as an effort to prevent unequal competition and systematic exploitation of the vulnerable community. Community empowerment should not increase the community's reliance on various charity programs. Because, basically, everything that they enjoyed must be produced on its efforts (the results may exchanged with other parties). Thus, the ultimate goal is to establish a society, enable, and build the ability to advance itself towards a better life on an ongoing basis. ${ }^{17}$

\section{Community Empowerment in Islam}

Developing the economy in Islam, the law is fardu kifayah in the empowerment of society in Islam. And, there is a fundamental in Surah Al-Hadid verse 25, which reads:

We have sent Our messengers with clear proofs and sent down the Book and the Balance with them so that humanity may exercise justice. And We created iron in which there was great strength and benefit for humankind, and that Allah may know who helped Him and His messengers when He did not see them. Indeed Allah is Strong and mighty.

And there is a basic written in the Hadith: "And whoever makes it easy for the hard-off, Allah will ease him in this world, and in the Hereafter. Allah always helps His human rights, as long as the servant wants to help his brother" (H.R. Muslim).

All the explanations show that Islam arranges to help each other to create an independent and empowered society by helping each other in goodness. One explicit goal is, to create a balance in the empowerment of society so that no society feels oppressed by other communities. So, it can also be explained that empowerment aims to help the community meet its needs. ${ }^{18}$

And, Islam has asserted both in the verses of the Quran and Hadith about the community's efforts consciously to make improvements/empowerment to build a community that has power to be financially independent, both educationally and prosperous in life. To create an expected society, it needs to joint efforts, both from the

${ }^{17}$ Refnita, "The Mustahik Zakat in Various Dimensions of Fiqh in Era Society 5.0."

${ }_{18}$ Zulhijjah Qurrotu Aini, "Role Government Deep Empowerment Economics Community Deep Achievement Mașlahah Community Local about Tour Garden Fruit Mangunan Imogiri Help" (Islamic University of Indonesia, 2018). 
community and the Government as having the right and authority to make the policies to empower the community. ${ }^{19}$

\section{Scope of Economic Empowerment of People in Islam}

Community empowerment can be conducted by governments, universities, nongovernmental organizations, the press, political parties, donor agencies, civil society actors, or local community organizations. ${ }^{20}$ The government element is the highest level and has greater power compared to other elements. Here, the empowerment will be more urgent if built with mutual trust and respect from the beginning. In empowerment, all elements are equal, and each element must understand each other and respect the interests and differences between elements. ${ }^{21}$

This empowerment can create motivation and inspiration for the community in an area to contribute more significantly. The facilitator's role is to entice citizens to participate in a program. Citizens' participation in a program fosters a sense of ownership in the program. In addition to the citizens' representatives who are responsible on implementing a program, the guidance also needs to convince the citizens that each citizen has various potentials to have benefit of mutual progress. Therefore, it is expected that every citizen will participate technically in the implementation of the empowerment program. Thus, the program will belong to the citizens, who also implement, and will be helpful for the citizens. ${ }^{22}$ And, in the era of the Commander of the Faithful Omar Ibn Al-Khattab, radiyallāhu 'anhu, is another vivid picture of economic empowerment to build a righteous person and protect society. When one of his governors asked:

What would you do if a thief came to you?" The governor said: I cut off his hand. Omar said: So if one of them came to me hungry or unemployed, I would cut off your hand, for God, Glory be to Him, has appointed us as successor over His servants to fill their hunger, cover their nakedness, and provide them with their craft before it preoccupies you with sin.

\footnotetext{
${ }^{19}$ Meirison and Kasmidin, "Types of Science and the Obligation of Muslim Communities to Study It," Tathwir 11, no. 2 (2020).

${ }^{20}$ Moid U. Ahmad and Athar Mahmood, "Zakat Fund: Concept and Perspective," International Journal of Monetary Economics and Finance 2, no. 3 (2009), https://doi.org/10.1504/IJMEF.2009.029058.

21 Aini, "Role Government Deep Empowerment Economics Community Deep Achievement MaṢlahah Community Local about Tour Garden Fruit Mangunan Imogiri Help.”

${ }^{22}$ Aini. 
Economic thoughts from the Prophet's guidance: on the authority of Rifa'a bin Rafi', may God be pleased with him that the Prophet PBUH was asked: Which earning is the best? He said: "A man's work is in his hand, and every sale is acceptable." (Narrated by Al-Bazzar and authenticated by Al-Hakim).

Economic Lessons in Hadith: first, the hadith mentions a man, and it is also for woman. Second, the return is only with effort and work. Third, the return may be in the form of wages for work for oneself or others, and profit through sale. And, this discussion is the sources of economic return. Fourth, the work with the hand takes precedence over the justified sale, which reflects the value of the effort that the individual exerts to obtain his earnings through his hand that engages in a work, whether on industrial, agricultural or commercial, that good at. In the Hadith: "No one has ever eaten food is better than eating from work, his hand" (Bukhari narrated), and the value of the preferred activity depends on the nation's need to realize it. Fifth, Trade is one of the best gains when it is free of taboos. For example, usury, ambiguity, gambling, cheating, fraud, deception, and consuming money unlawfully, and justified sale free of these taboos is an exchange that achieves the value of justice and mutual benefit in society. Through it, a fair price is achieved without tyranny or loss. Sixth, The man's work with his own hands and the acceptable sale are both wings of the return achieved in the economy. With them, the financial blessing is achieved in the life of its owner, and thus, their owner combines material gain and moral gain, and the benefits from both blessed and sustenance. ${ }^{23}$

In economic empowerment, in Islam, it is necessary for the imprisoner in the religion in the school to explain the economy and the meaning of wealth. And it is also necessary to emphasize in the context of figh that to become an affluent person must be done in a good and moral way. Wealth, according to Islam, is said to be important because that wealth can perfect the pillars of Islam. It is necessary to explain that society needs to create a work and see the potential of becoming entrepreneurs with a strong disposition and ready to face global economic competition. ${ }^{24}$

23 Meirison Alizar Sali, Desmadi Saharuddin, and Rosdialena, "Takhrij Juriscprudence and Problems Contemporary," Al-Istinbath $\quad 5, \quad$ no. $1 \quad$ (2020): 51-57, https://doi.org/doi.org/10.29240/jhi.v5i1.1235.

${ }^{24}$ Sali, Saharuddin, and Rosdialena. 
Therefore, Islamic education affirms to the community that they need to be rich, but not necessary to earn money. The truth of money, according to Islam, is not the primary purpose but as a complement in perfecting worship as zakat and hajj. Max stated that the economic community empowerment in Islam is required for sustainable development by the Government and religious institutions around the community, such as coaching and training, namely: business training, internship, proposal preparation, capital, mentoring, and business network. ${ }^{25}$

Empowering the community economy is not enough to provide its means to train the skills of the community. However, an effort is required to be able to generate insights and community spirit in entrepreneurship. This Spirit and insight will be created by systematically extracting potential so that the public can see the opportunities in the environment that can be developed. ${ }^{26}$

\section{Government Policies in Economic Empowerment of Muslim Communities in the Digital Economy Era}

The role of the government is performed in a positive form, which provides convenience in carrying out an activity. In community empowerment, which refers to the community itself developing and becoming independent, it is also necessary to participate from the Government to develop it. ${ }^{27}$

According to Ibn Taymiyah, the need for human beings to govern is affirmed in revelation and reinforced by the laws of nature or reason involving people joining and cooperating. From various previous explanations, it is proven that the quality of the Islamic State is in its proficiency and ability to implement and realize the sharia principles. Thus, power does not lie with the Islamic State's leadership or the people but Allah is the primary legislator.

In Umer Chapra's theory, the role of the Government in the economic empowerment of the community is essential because the Government's role will provide a positive result and be oriented following the objectives in the economy. The

${ }^{25}$ Meirison, "Administration and Finance System of the Ottoman Empire," Al-Syir'ah 18, no. 2 (2020), https://doi.org/10.30984/jis.v18i2.1113.

${ }^{26}$ Meirison.

27 Aini, "Role Government Deep Empowerment Economics Community Deep Achievement MaṢlahah Community Local about Tour Garden Fruit Mangunan Imogiri Help.”

https://e-journal.iain-palangkaraya.ac.id/index.php/maslahah/index 
Government's role is complementary by internalizing Islamic values in society, creating a healthy socioeconomic climate, and developing the right institutions. ${ }^{28}$

In theory, given by Umer Chapra, there is a verse that serves as one of the fundamental in his theory. The verse is surah Al-Baqarah verse 256: "There is no compulsion to (enter) religion (Islam); Surely, the right path is clear from the gone way. So, whoever disbelieves in Tagut and believes in Allah has grasped the knot of a strong rope that will not break. And Allah is All-Hearing, All-Knowing".

The essence of the paragraph is that the role of the Government to create objectives related to the economy of society does not need to use the wrong way and prohibited. Therefore, the Government must be wise in applying Islamic law.

According to Islam, the purpose of the Government's role in empowering society's economy is to create prosperity or sharia maqașid for the whole community, not a group of parts or individuals. The expected goal when the Government carrying out its role to obtain sharia maqāsid is: first, the fulfilment of people's living needs. With available natural resources, it can be used to meet the basic needs of the community. The natural resources are limited, and it needs to limit the collection of resources. The resource collection is only for the needs of the general public and not individuals, and the priority is poor.

Second, the source of income obtained by the community is halal. Every individual from the community is obliged to make a living to guarantee his family life, so everyone is obliged to have the same opportunity to make a living honestly and fairly. And, if there are people who cannot afford to make a living because of physical limitations, then it becomes the Government and the community's duty to help him meet the needs.

Third, Fair distribution of income and wealth. Although society has been able to meet its needs, there is still a gap in income and wealth in Islam. As long as the gap is still average and not too different, it is considered reasonable. Then, it is necessary for people who have more income to give to people who have low income or need it. Because the real wealth obtained is the deposit, and the some must be given. Therefore, there needs to be a fair distribution of wealth between peoples. Fourth, it can create

\section{${ }^{28}$ Aini.}


growth and stability. To realize people's needs, the need for stability and economic growth is narrow the excessive disparity between rich and poor people. ${ }^{29}$

In order to create an advanced area, it needs to know in advance in terms of which area it is and how it is in an area. Create an advanced area that can be divided into several facts.

First, as a Process, is a change from a society that traditionally lives to more advanced. In this sense, it is necessary to change society's social and psychological sides. Second, as a Method, is an effort for people to develop themselves with their abilities and potentials. Third, as a Program aims to improve the community's standard of living and welfare, which tends to be emphasized in terms of education, skills, health, industry, cooperatives, and so forth. Fourth, as a Movement aims to create an advanced society. Here, it is necessary to emphasize the underlying ideological framework and direct the processes, methods and programs to advance the village. ${ }^{30}$

With many problems in an area, such as low income, it takes an effort to solve the problem. Then management must manage the problem. The target in the progress of this area is in the community. It needs to improve the community's ability and standard of living and welfare in this case. With the progress of this area, it can also accelerate the growth and development of socioeconomic in the area. Currently, advance an area that tends to take precedence is in the economic field, so all efforts made refer to its economic development. As for other fields need to be developed but only as a support and complement only. ${ }^{31}$ The mechanism in developing an area is by combining activities or programs from the Government to develop a region and community participation activities that grow from the bottom with the awareness and responsibility of the community. It needs for a sense of responsibility with changes in mental attitudes, a view of life's way of thinking, and improving knowledge and skills.

In developing an area, good coordination is required from the central level to the community level that aims to achieve the desired benefits and objectives in developing the area. So, in this case, the Government, as the top-level, must be agile and fast to

\footnotetext{
29 Aini.

30 Aini.

31 Meirison and Desmadi Saharuddin, "The Distinction of Government Administration and Judicial Institutions in the Umayyad Dynasty," Al-Turas 27, no. 1 (2021), https://doi.org/10.15408/bat.v27i1.17286.
} 
develop. The Government mut be not slow in managing related to the development of area because the Government is also an important aspect to create the development in a village, and several steps can be done, among others:

a. Providing and expanding employment in rural areas, both the agricultural sector, small industries, people's handicrafts, and village entrepreneurship businesses, improving and developing labor-intensive programs and so on.

b. To revive and grow the village economy cooperatively towards cooperative efforts.

c. Expanding the network and improve the village infrastructure network, including production infrastructure, economic infrastructure, transportation and communication infrastructure, and social infrastructure.

d. Improving the productivity and welfare of the villagers by restoring housing and the village environment.

e. Improving the development of knowledge skills of villagers.

f. Improving the efforts of counselling to rural areas through various media.

g. Expanding rural health facilities, especially the community health center, the provision of clean water and other sanitation facilities.

h. Develop and improve the effectiveness of village unit cooperatives as a forum for activities in developing the village economic sector.

i. Develop and increase community participation as a forum for activities in the field of a village development.

j. Improving the village government apparatus to carry out its functions properly.

k. Develop and strengthen the implementation of comprehensive and integrated village development.

1. Develop and expand the development of family welfare by increasing the role of women as a whole. ${ }^{32}$

With all the steps that aim to create a goal to develop an area, it depends entirely on the implementation, both the Government and the community. If has the willing to develop of an area, the shared responsibility is required with the Government. So, natural explanations by Nanih Machendrawaty and Agus Ahmad Safe in his book,

\footnotetext{
${ }^{32}$ Meirison and Saharuddin.
} 
Islamic Community Development, offering three empowerment complexes. The first, empowerment in the eyes of Spirit, or known as the morals of Indonesian society now tend always to follow the negative culture of the west. Therefore, Muslims must fight hard to establish the design of an educational curriculum oriented to the total empowerment of ruhaniah Islamiyah. Second, intellectual empowerment, Indonesia can now be far behind other countries in terms of progress and mastery of science and technology. Therefore, it takes a great struggle from the return of educational orientation to intellectual development. Third, economic empowerment must be admitted that poverty and lag have become synonymous with most Muslims, especially in Indonesia. And, a strategy and policy is needed to get out of the gap and economic inequality. ${ }^{33}$

The role of the Government is in favorable terms, which helps the community realize the welfare and balance between social and individual interests, and maintain the economy in the environment always to be balanced and prevent any misappropriation related to personal interests. In addition to the above roles, the Government also needs to do its economic empowerment. In this case, five policies that the Government can empower the community economy, are:

a. Animating the Human Factor

The need for motivation to create a spirit for the community in developing their environment and motivation makes people need to have access to finance to create a better environment. This motivation might not be done without understanding moral consciousness, where this awareness needs to complete to avoid conflict between personal and social interests.

b. Reducing Wealth Concentration

Aim to reduce the concentration in this wealth, through developing microbusinesses in the environment and decentralizing decision making.

c. Economic Restructuring

Through restructure the economy is to fulfil life needs between need and want, and give excess wealth to other communities in need.

d. Restructuring Finance

33 Aini, "Role Government Deep Empowerment Economics Community Deep Achievement MaṢlahah Community Local about Tour Garden Fruit Mangunan Imogiri Help.”

https://e-journal.iain-palangkaraya.ac.id/index.php/maslahah/index 
This financial restructuring needs to conduct thoroughly so that financial institutions can eliminate imbalances and fair and efficient intermediation of the source of the finance. So that the rich do not increasingly oppress the poor. The role of financial institutions is also to give rights to people who have efforts to obtain funding from financial institutions. Therefore, the financial institution must follow the Islamic system, which is more conducive and solution.

e. Strategic Policy Planning

Create an empowered environment, and strategic policy planning is needed in the long-term. With this plan, the state will do a realistic calculation of the available physical and human resources, and follow its priorities. With this policy, the Government or private sector contributes a significant amount. The plan that needs for the community is to use scarce resources efficiently and fairly, and it is necessary to articulate Islamic values in terms of savings, consumption, and investment, and work ethic.

\section{Conclusion}

According to Islam, the purpose of the government policies in economic empowerment of muslim communities in the digital economy era is to create prosperity or maqāsid syari'ah for the whole community, neither a group nor individuals. Community empowerment is focused on various aspects related to people's lives as a nation's society, namely empowerment in the fields of education, economy, socioculture, psychology, and politics in the era of the digital economy. In the era of Amirul Mukminin bin Al-Khattab as the second caliph, he ran the government firmly but was very sensitive to his people. The issued policies were for the benefit of the people, not only Muslims but also all citizens who live under the Umar's caliphate. These policies in community empowerment during Umar's time should be interpreted in the current context. The era known as the digital age, of course, needs to modify the policies of the past, so that they can be relevant and be applied.

\section{BIBLIOGRAPHY}

Abdurrahman. Encyclopedia Economics, Finance and Trade: English-Indonesia. Jakarta: Pradnya Paramita, 1991.

Ahmad, Moid U., and Athar Mahmood. "Zakat Fund: Concept and Perspective." International Journal of Monetary Economics and Finance 2, no. 3 (2009). https://doi.org/10.1504/IJMEF.2009.029058. 
Ahmad, Sabarudin. "Hukum Aborsi Akibat Perkosaan (Analisis Hukum Islam Terhadap Peraturan Pemerintah Nomor 61 Tahun 2014 Tentang Kesehatan Reproduksi." ElMashlahah 8, no. 2 (2018): 162-83. https://doi.org/https://doi.org/10.23971/elmas.v8i2.1321.

Aini, Zulhijjah Qurrotu. "Role Government Deep Empowerment Economics Community Deep Achievement MaṢlahah Community Local about Tour Garden Fruit Mangunan Imogiri Help.” Islamic University of Indonesia, 2018.

Assi, Eman. "Islamic Waqf and Management of Cultural Heritage in Palestine." International Journal of Heritage Studies 14, no. 4 (2008): 380-85. https://doi.org/10.1080/13527250802156180.

Batubara, Zakaria. "Islam Dan Pemberdayaan Ekonomi Umat." Iqtishaduna 2, no. 2 (2013): https://ejournal.stiesyariahbengkalis.ac.id/index.php/iqtishaduna/article/view/34.

Gufron, Moh. Idril. "Peningkatan Produksi Dalam Sistem Ekonomi Islam Sebagai Upaya Pemberdayaan Umat." Dinar: Jurnal Ekonomi Dan Keuangan Islam 2, no. 1 (2015). https://journal.trunojoyo.ac.id/dinar/article/view/2690.

Labaran, Muhammad Azran, Lukman Hakim, and Rudi Hardi. "The Role of The Local Government in the Empowerment of Cocoa Farmers Community in Taan Village, Tapalang District, Mamuju Regency." Otoritas: Jurnal Ilmu Pemerintahan 4, no. 1 (2014). https://doi.org/0.26618/ojip.v4i1.80.

Meirison. "Administration and Finance System of the Ottoman Empire." Al-Syir'ah 18, no. 2 (2020). https://doi.org/10.30984/jis.v18i2.1113.

Meirison, Fadhilah Insani, and Zahara Andini. "Epistemology of Basic Concepts of Spiritual and Physical Thaharah: Analysis of The Benefits of Ablution Spiritually and Physically." Al-Insyiroh 7, no. 1 (2021): 26-43. https://doi.org/10.35309/alinsyiroh.v7i1.4080.

Meirison, and Kasmidin. "Types of Science and the Obligation of Muslim Communities to Study It." Tathwir 11, no. 2 (2020).

Meirison, and Zerly Nazar. "Intellectual Property Rights and Monopoly in the Perspective of Islamic Jurisprudence." Al-Ahkam 31, no. 1 (2021): 49-68. https://doi.org/10.21580/ahkam.2021.31.1.6656.

Meirison, and Desmadi Saharuddin. "The Distinction of Government Administration and Judicial Institutions in the Umayyad Dynasty." Al-Turas 27, no. 1 (2021). https://doi.org/10.15408/bat.v27i1.17286.

Midgley, James. Social Development: The Development Perspective in Social Welfare. London: Thousand Oaks Calif, 1995.

Prijono, Onny S., and A.M.W. Pranarka. Empowerment: Concept, Policyand Implementation. Jakarta: Centre for Strategic and International Studies, 1996.

R, Suharyono A. Role Government, Empowerment Society, and Enforcement Law Depp Countermeasures Logging Wild. Jakarta: Yayasan Pustaka Torch Indonesia, 2018.

Refnita, Desi. "The Mustahik Zakat in Various Dimensions of Fiqh in Era Society 5.0." 
El-Mashlahah 11, no. 1 (2021): 13-28. https://doi.org/10.23971/elma.v11i1.2285.

Rukminto, Adi Isbandi. Empowerment, Development Society, and Intervention Community. Jakarta: F-UI, n.d.

Sali, Meirison Alizar, Desmadi Saharuddin, and Rosdialena. "Takhrij Juriscprudence and Problems Contemporary." Al-Istinbath 5, no. 1 (2020): 51-57. https://doi.org/doi.org/10.29240/jhi.v5i1.1235.

Sumodiningrat. Empowerment Society and Dragnet Safety Social. Jakarta: Gramedia Pustaka Utama, 1999. 